\title{
Potensi Banjir Bandang Pada Wilayah Sigi Sulawesi Tengah Indonesia
}

\author{
Riki Chandra Wijaya \\ Program Studi Teknik Sipil, FT UNILA, Bandar Lampung \\ e-mail: riki.chandra@eng.unila.ac.id
}

Received 22 February 2021; 25 February 2021; Accepted 26 August 2021

Journal Homepage: http://jurnal.borneo.ac.id/index.php/borneoengineering

\begin{abstract}
Flash floods are a dangerous disaster for a region. A large quantity of surface water at a high velocity will give a large momentum to all objects in its path. This will certainly have a big impact on the damage it will produce. The Sigi region, Central Sulawesi, Indonesia based on information on disaster events, is an area that is often hit by flash floods. For this reason, a study of the potential for banjir bandang is do in this research. Based on data on flood events in 2017, this analysis was using daily rainfall data in 2017 in the Sigi, Central Sulawesi area. Based on the analysis, it is known that the potential for flooding that occurs has a depth of up to $70 \mathrm{~cm}$ with a flow rate of up to $0.085 \mathrm{~m} / \mathrm{sec}$. Based on the results of this analysis, the flood-affected area is very large, almost all the flood-affected areas. The flat topography causes the puddle area to spread more easily. The sharp slope in the upstream area causes flooding to come on suddenly. For this reason, the potential for flooding from the results of this analysis is expected to be the basis for further research in overcoming this problem.
\end{abstract}

Keywords: Flash Flood; Sigi Central Sulawesi Indonesi; Analysis of Potential.

\begin{abstract}
Abstrak
Banjir bandang merupakan salah satu bencana yang berbahaya bagi suatu wilayah. Kuantitas air permukaan yang besar dengan kecepatan yang tinggi akan memberikan momentum yang besar pada seluruh objek yang dilewatinya. Hal ini tentu akan memberikan dampak yang besar terhadap kerusakan yang akan dihasilkannya. Pada wilayah Sigi Sulawesi Tengah berdasarkan informasi kejadian bencana merupakan daerah yang sering dilanda banjir bandang. Untuk itu, kajian potensi banjir bandang ini dilakukan dalam penelitian ini. Berdasarkan data kejadian banjir pada tahun 2017 maka analisis ini dilakukan menggunakan data curah hujan harian pada tahun 2017 di daerah Sigi Sulteng dilakukan analisis hidrologi menggunakan metode hujan rata-rata jam-jaman Mononobe. Periode ulang curah hujan tersebut dianalisis dengan Metode Gumbel berdasarkan hasil evaluasi pemilihan metode. Berdasarkan hasil analisis diketahui potensi banjir yang terjadi memiliki kedalaman hingga $70 \mathrm{~cm}$ lebih dengan kecepatan aliran mencapai 0,085 m/detik. Daerah yang terdampak banjir berdasarkan hasil analisis ini sangatlah besar hampir semua wilayah terdampak banjir. Kondisi topografi yang mendatar menyebabkan area genangan air akan lebih mudah menyebar. Kemiringan yang tajam pada wilayah hulu menyebabkan banjir berpotensi datang secara tiba-tiba. Untuk itu, potensi banjir dari hasil analisis ini diharapkan dapat menjadi dasar dalam penelitian selanjutnya dalam mengatasi permasalahan ini.
\end{abstract}

Kata kunci: Banjir Bandang; Sigi Sulawesi Tengah Indonesia; Analisis Potensi 


\section{Pendahuluan}

Daerah Aliran Sungai Palu berada di Sulawesi Tengah, Indonesia. Daerah ini secara topografi memiliki elevasi yang hampir sama pada daerah cekungannya. Luasan cekungan DAS yang begitu besar dilalui oleh sungai utama yaitu Sungai Palu. Ratusan rumah di Palu, Ibu Kota Provinsi Sulawesi Tengah terendam akibat Sungai Palu meluap menyusul hujan deras di bagian hulu sungai itu (Yudi, 2017). Selain DAS Palu secara bagian besar, Daerah Sigi pun pada tahun 2020 menyatakan waspadaan akan datangnya banjir. Hal ini disampaikan Bupati Sigi, Mohammad Irwanm Lapata "Semua SKPD terkait tetap waspada dan segera melakukan kegiatan jika terjadi bencana banjir maupun tanah longsor" (Sasongko, 2020). Apabila masyarakat telah mengetahui besaran dampak ini maka diharapkan masyarakat yang tinggal di Daerah Aliran Sungai dapat menyesuaikan diri terhadap kondisi alamiah lingkungannya. Daerah aliran sungai (DAS) khususnya mulut muara di Sungai Palu dikhawatirkan ada banyak material menumpuk di daerah hulu hingga membentuk sebuah hambatan. Kondisi tersebut bisa menyebabkan banjir bandang lantaran air menumpuk di musim hujan (Indonesia, 2018). Pada tahun 2017, Daerah Aliran Sungai Palu mengalami banjir besar ratusan rumah di Palu, Ibu Kota Provinsi Sulawesi Tengah terendam akibat Sungai Palu meluap dengan tingkat kerugian yang besar (ANTARA, 2017). Salah satu wilayah yang sering dilanda banjir bandang ialah Kabupaten Sigi, Sulawesi Tengah. Banjir bandang yang terjadi telah banyak menyebabkan kerugian materil dan korban jiwa. Berdasarkan catatan sejarah pada tahun 2012 Kabupaten Sigi dilanda banjir bandang dan menyebabkan dua orang meninggal dunia dan seratus rumah lebih mengalami kerusakan akibat terpaan banjir bandang yang membawa batu-batu besar disertai lumpur padat. (Litha, 2019)

\section{Metode Penelitian}

Penelitian ini dilakukan pada bulan Nopember sampai dengan Desember 2020 berlokasi di Daerah Aliran Sungai Palu, Sulawesi Tengah. Bahan dan alat yang digunakan dalam penelitian ini meliputi seperangkat komputer dengan spesifikasi yang sesuai, perangkat lunak pengolah citra, perangkat lunak HEC-Hidrology Management System tipe 4.5, dan perangkat lunak HEC-River Analysis System tipe 5.0.3. Besaran dampak hidrologi yang terjadi di Daerah Aliran Sungai Palu dapat diketahui dari tinggi hujan yang terjadi. Kondisi topografi DAS Palu menjadi informasi akan kemampuan DAS Palu dalam menyerap air. Dalam penelitian ini digunakan data curah hujan harian pada tahun 2017 yang bersumber dari:

$\begin{array}{ll}\text { ID WMO } & : 97072 \\ \text { Nama Stasiun } & : \text { Stasiun Meteorologi Mutiara Sis-Al Jufri } \\ \text { Lintang } & :-0.91589 \\ \text { Bujur } & : 119.90554 \\ \text { Elevasi } & : 79\end{array}$

Selanjutnya data hujan tersebut dianalisis secara hidrologi untuk memperoleh debit rencana dengan menggunakan metode hydrograph satuan pada kondisi DAS Palu.

Soil Conservation Service (SCS) Curve Number (CN) model perhitungan hujan sebagai suatu fungsi dari jumlah kumulatif hujan, lapisan terluar tanah, tata guna lahan, dan penguapan pada lahan, menggunakan persamaan 1 di bawah ini,

$$
P_{e}=\frac{\left(P-I_{a}\right)^{2}}{P-I_{a}+S}
$$




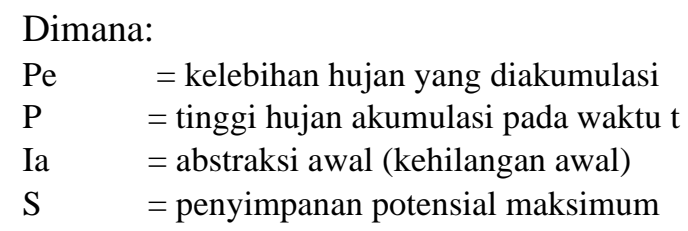

Berdasarkan laporan analisis dari banyak eksperimen kecil, SCS dikembangkan sebagai hubungan empirik dari Ia dan S:

$$
\mathrm{I}_{\mathrm{a}}=0.2 \mathrm{~S}
$$

Kemudian, kelebihan kumulatif pada waktu t adalah:

$$
P_{e}=\frac{(P-0.2)^{2}}{P+0.8 S}
$$

(Scharffenberg dan Flaming, 2009)

Hasil analisis yang dilakukan dapat berupa hidrograf. Hidrograf satuan adalah suatu luasan grafik yang digunakan sebagai konsep dalam hidrologi. Hidrograf satuan dapat digunakan untuk membuat respon hidrologi pada kejadian hujan yang didasarkan pada tiga prinsip yaitu:

1. Ketetapan: waktu yang didasarkan dari hidrograf satuan adalah konstan, tanpa memperdulikan intensitas hujan.

2. Proporsionalitas: ordinat dari hidrograf limpasan yang sebanding untuk volume hujan efektifterhadap intensitas hujan dan rata-rata aliran.

3. Superposisi: respon untuk balok berturut-turut dari hujan efektif, masing-masing mulai pada waktu tertentu, dapat memprediksi kejadian hujan dengan menggunakan penggabungan dua buah hidrograf.

Pendekatan ini merupakan pendekatan linier (disebut convolution) secara jelasnya pada persamaan 4 berikut ini,

$$
\begin{gathered}
(t)=\sum_{\omega=1}^{N} u(D, j) I_{\omega} \\
Q(t)=u(D, j) I_{1}+u(D, t-D) I_{2}+\cdots+(D, t-(N-1) D) I_{n}
\end{gathered}
$$

Dimana:

$\mathrm{Q}(\mathrm{t}) \quad=$ ordinat hidrograf limpasan pada waktu $\mathrm{t}\left(\mathrm{m}^{3} / \mathrm{detik}\right)$

$\mathrm{u}(\mathrm{D}, \mathrm{j}) \quad=\mathrm{D}-\mathrm{h}$ ordinat hidrograf satuan pada waktu $\mathrm{j}\left(\mathrm{m}^{3} /\right.$ detik $)$

I_ $\omega \quad=$ ketinggian hujan dalam $\omega$ th dari N Blok pada durasi D $(\mathrm{m})$

$\mathrm{j} \quad=\mathrm{t}-(\omega-1) \mathrm{D}(\operatorname{detik})$

(Butler dan Davies, 2014)

\section{Hasil dan Pembahasan}

Penelitian ini berdasarkan kondisi topografi dari DAS Palu serta kondisi meteorologi di lingkungannya. Berdasarkan sejarah kejadian banjir pada tahun 2017 yang menjadi dasar dalam analisis ini terjadi banjir dengan kuantitas yang besar. Kejadian pada tahun 2017 ini menjadi pertimbangan dalam pengamatan akan potensi banjir yang terjadi secara berulang. Oleh sebab itu, analisis ini menggunakan data kejadian hujan pada tahun 2017. Curah hujan harian pada tahun 2017 ditunjukkan pada grafik hujan sebagai berikut. 


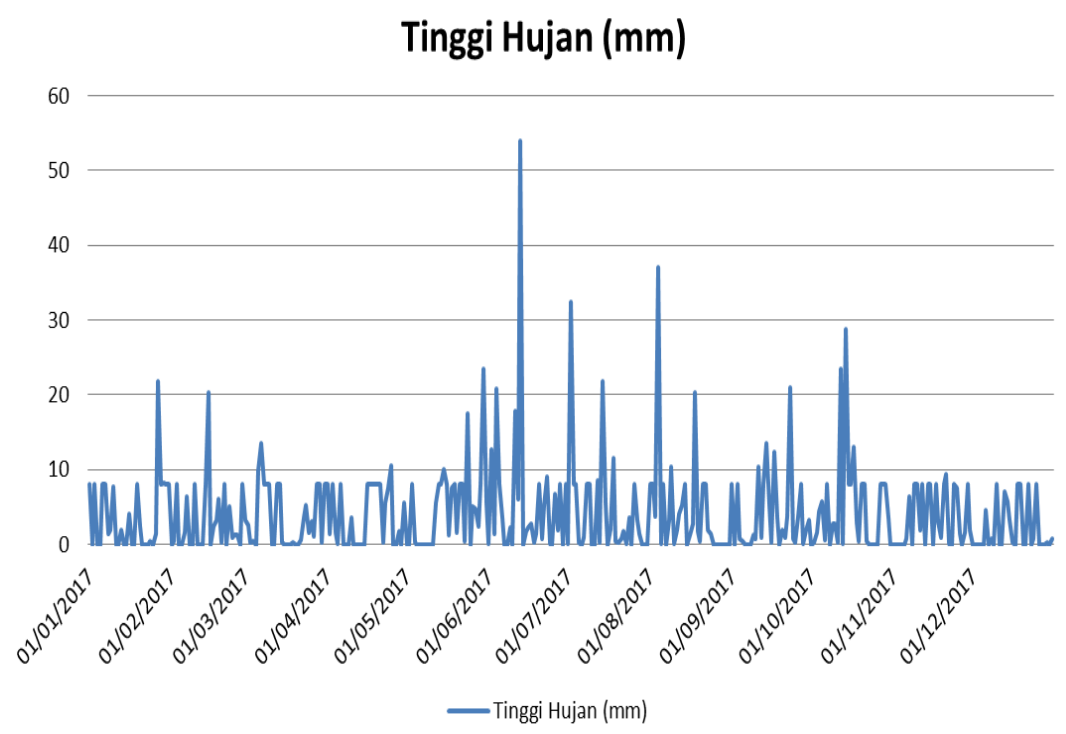

Gambar 1. Kondisi Tinggi Hujan pada tahun 2017 (Sumber: Hasil Analisis, 2021)

Berdasarkan grafik di atas terlihat adanya kejadian hujan yang ekstrem diantara bulan Juni sampai dengan Juli. Kejadian curah hujan ekstrem ini memungkinkan menimbulkan banjir pada DAS Palu. Selain itu, kondisi Daerah Aliran Sungai Palu memiliki tingkat elevasi yang relatif datar. Hal ini menjadi penyebab penyebaran banjir akan lebih mudah dan dapat mengakibatkan dampak yang besar. Kondisi lahan yang sudah berubah dari area resapan menjadi area kedap semakin bertambah dari tahun ke tahun. Hal ini ditunjukkan sebagaimana pada gambar 2. Sebagian besar wilayah DAS telah dilakukan perubahan tata guna lahan, hal ini dapat ditunjukkan dengan perubahan tata guna lahan dari tahun. Perubahan tata guna lahan tersebut dapat terlihat dari beberapa potongan gambar google earth seperti yang ditunjukkan gambar no 2 berikut ini,

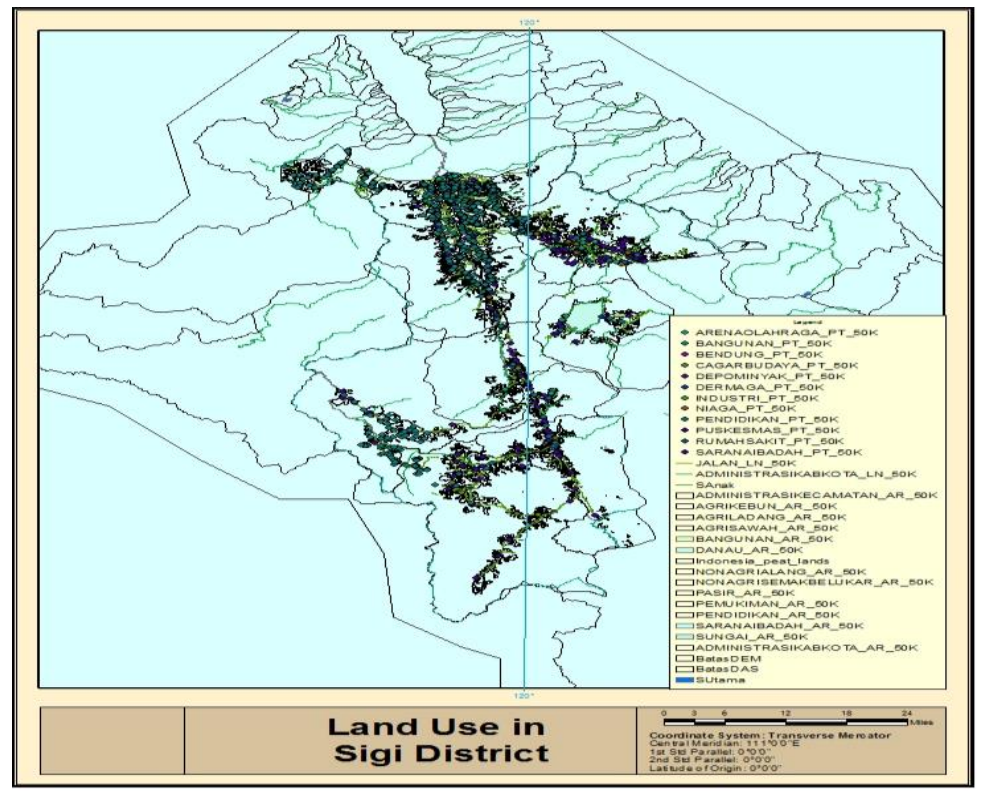

Gambar 2. Kondisi Land Use pada Daerah Aliran Sungai Palu Sumber: Hasil Analisis, 2021

Pada gambar 2 terlihat aliran sungai meningkat pada tahun 2017 dengan luas genangan yang lebih besar dari tahun sebelumnya. Peningkatan tersebut terlihat dari luas genangaan air yang melalui 
penampang sungai utama. Hal ini tentu memberikan informasi akan adanya luapan air sungai. Model hidrologi Daerah Aliran Sungai Palu dibuat dengan bentuk sebagaimana pada gambar 3 di bawah ini,

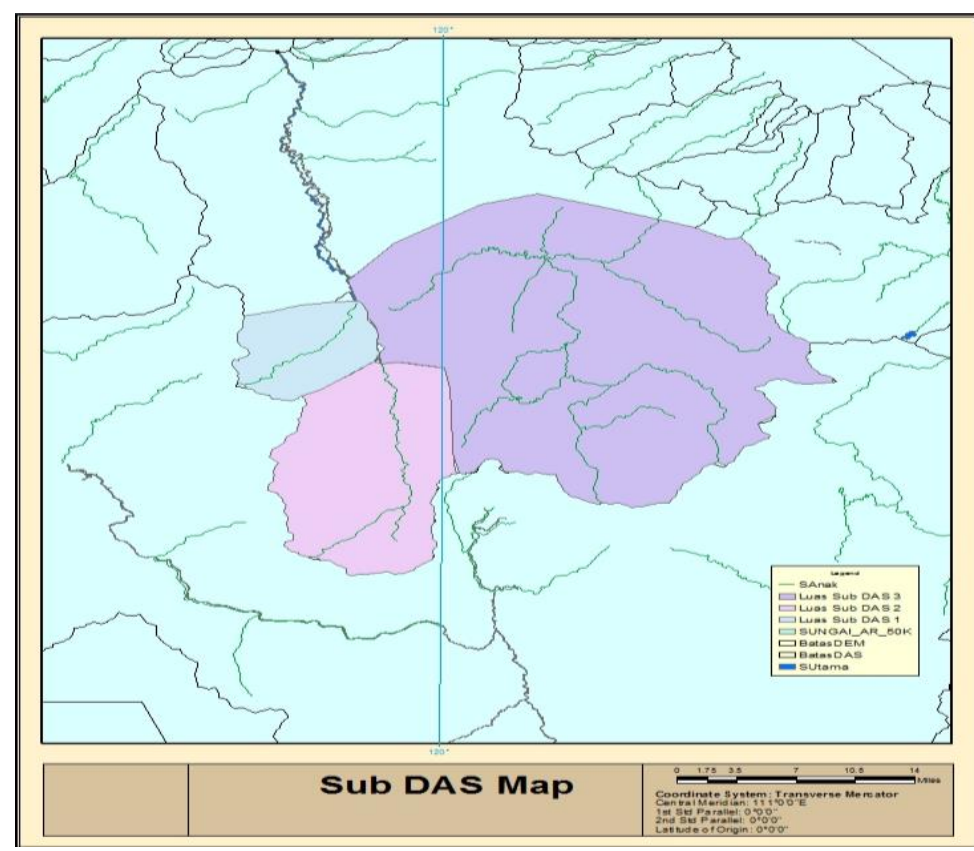

Gambar 3. Model Hidrologi Daerah Aliran Sungai Palu

Sumber: Hasil Analisis, 2021

Gambar 3 menunjukkan terdapat tiga sub DAS dalam analisis ini, masing-masing sub DAS akan mengalirkan aliran permukaan menuju titik pengukuran. Masing-masing luas Sub DAS ditentukan berdasarkan kondisi topografi yang ada. Berdasarkan pengukuran diketahui luas masing-masing Sub DAS sebagaimana tabel 1.

Tabel 1 Luas Sub DAS di DAS DAS Palu

\begin{tabular}{|c|c|c|}
\hline No & Sub DAS & Area $\left(\mathrm{Km}^{2}\right)$ \\
\hline 1 & Sub DAS 2 & 422,8 \\
\hline 2 & Sub DAS 3 & 1435,8 \\
\hline 3 & Sub DAS 1 & 140,4 \\
\hline
\end{tabular}

Sumber: Hasil Analisis, 2021

Sub-DAS 3 memiliki luasan yang lebih besar dengan tingkat kepadatan penduduk yang lebih besar sehingga dampak terhadap faktor imperviousnya lebih besar pula. Tingkat kehilangan air disaat hujan dari tiga Sub DAS memiliki perbedaan sebagaimana pada tabel 2.

Tabel 2 Tingkat Impervious Sub DAS

\begin{tabular}{|c|c|c|}
\hline No & Sub DAS & Impervious (\%) \\
\hline 1 & Sub DAS 2 & 50 \\
\hline 2 & Sub DAS 3 & 75 \\
\hline 3 & Sub DAS 1 & 25 \\
\hline
\end{tabular}

Sumber: Hasil Analisis, 2021

Volume air limpasan dari masing-masing Sub DAS memiliki kuantitas yang berbeda juga disebabkan perbedaan luasnya. Waktu konsentrasi aliran permukaan masing-masing Sub DAS 
tentu berbeda satu sama lain. Tingkatan waktu konsentrasi masing-masing Sub DAS diketahui sebagai berikut.

Tabel 3 Time of Concentration Sub DAS

\begin{tabular}{|c|c|c|}
\hline No & Sub DAS & Time of Concentration (HR) \\
\hline 1 & Sub DAS 2 & 4 \\
\hline 2 & Sub DAS 3 & 9 \\
\hline 3 & Sub DAS 1 & 2 \\
\hline
\end{tabular}

Sumber: Hasil Analisis, 2021

Berdasarkan hasil perhitungan tabel 3 aliran permukaan yang terjadi pada wilayah studi diperoleh debit aliran input sebesar:

Tabel 4 Debit Puncak dan Volume Aliran

\begin{tabular}{lllll}
\hline \multicolumn{1}{c}{ Elemen Hidrologi } & Luas $\left(\mathbf{K m}^{2}\right)$ & Debit Puncak $\left(\mathbf{m}^{3} / \mathbf{s}\right)$ & Waktu Puncak & Volume $\left(\mathbf{1 0 0 0 ~}^{\mathbf{3}}\right)$ \\
\hline Subbasin-2 & 422.8 & 132.1 & 13Jun2017, 06:15 & 301667.8 \\
Subbasin-3 & 1435.8 & 872.4 & 13Jun2017, 14:15 & 1701921.3 \\
Reach-2 & 1435.8 & 872.4 & 13Jun2017, 14:30 & 1701921.3 \\
Reach-1 & 422.8 & 132.1 & 13Jun2017, 06:45 & 301667.8 \\
Subbasin-1 & 140.4 & 21.9 & 13Jun2017, 13:30 & 50087.7 \\
Junction-1 & 1999.0 & 1026.5 & 13Jun2017, 13:00 & 2053676.8 \\
\hline
\end{tabular}

Sumber: Hasil Analisis, 2021

Hasil pada tabel 4 menunjukkan besar debit puncak aliran permukaan pada titik tinjauan sebesar $1026,5 \mathrm{~m}^{3} /$ detik. Debit puncak ini akan bertambah disepanjang aliran sungai dengan masukkan aliran permukaan dari Sub DAS setelahnya hingga menuju ke laut. Grafik debit aliran disepanjang tahun 2017 terlihat pada gambar 4.

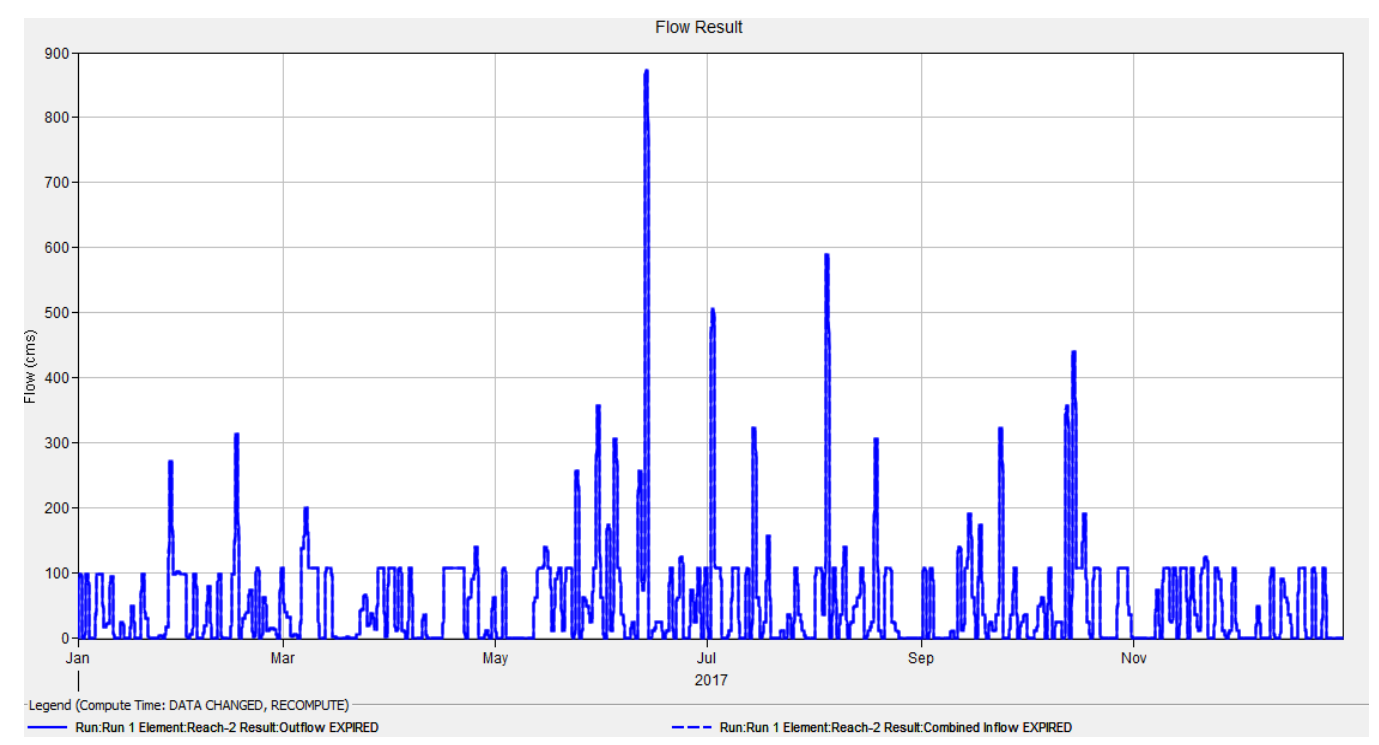

Gambar 4. Kondisi Aliran Air Permukaan pada Tahun 2017

Terlihat dari grafik di atas terdapat satu waktu debit aliran permukaan akan mencapai titik tertinggi dan hal ini menunjukkan akan adanya potensi terjadinya banjir bandang di Daerah Aliran Sungai 
Palu. Bentuk aliran yang terjadi dapat diprediksi dengan menggunakan analisis hidrolika pada penampang sungai utama.

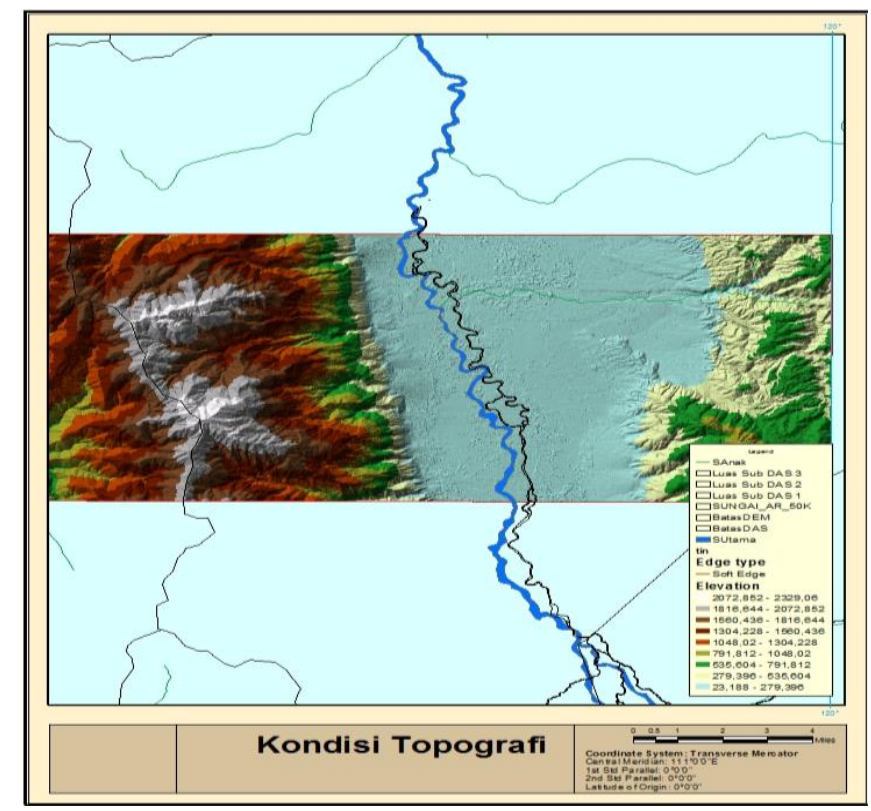

Gambar 5. Peta Topografi DAS Palu

Berdasarkan peta elevasi di potongan Daerah Aliran Sungai Palu terlihat kondisi topografi yang datar. Potensi banjir sangat besar terjadi di daerah ini disebabkan mudahnya penyebaran aliran permukaan di seluruh bagian. Pada lokasi kajian dilakukan simulasi banjir yang terjadi berdasarkan curah hujan pada tahun 2017. Tingkat kecepatan aliran air permukaan yang terjadi pada wilayah kajian diketahui sebagaimana pada gambar 6.

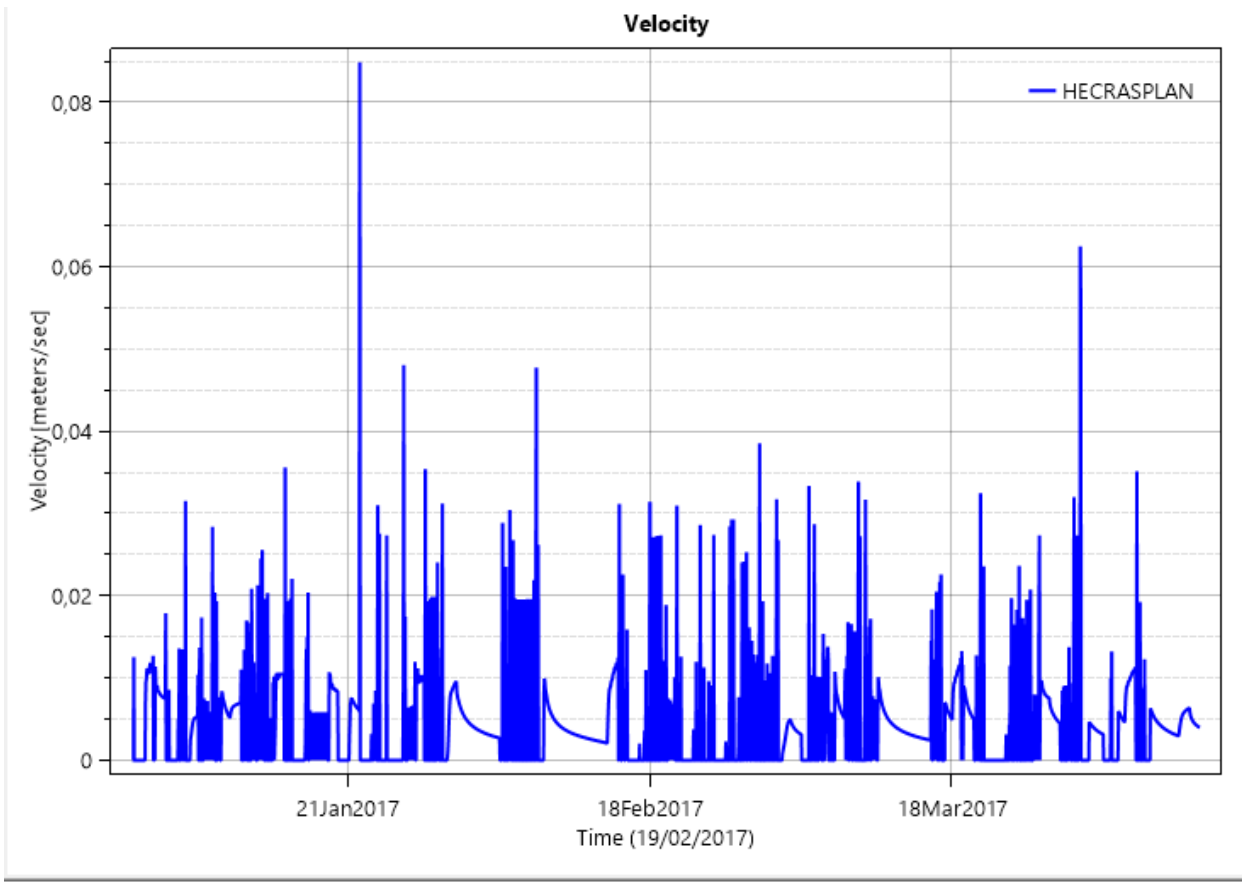

Gambar 6. Kondisi Kecepatan Air Permukaan 
Berdasarkan gambar 6 terlihat adanya puncak kecepatan air permukaan yang terjadi secara tiba-tiba hingga mencapai kecepatan aliran 0,085 $\mathrm{m} /$ detik. Wilayah tergenang banjir pada curah hujan tahun 2017 terlihat sebagaimana pada gambar 7.

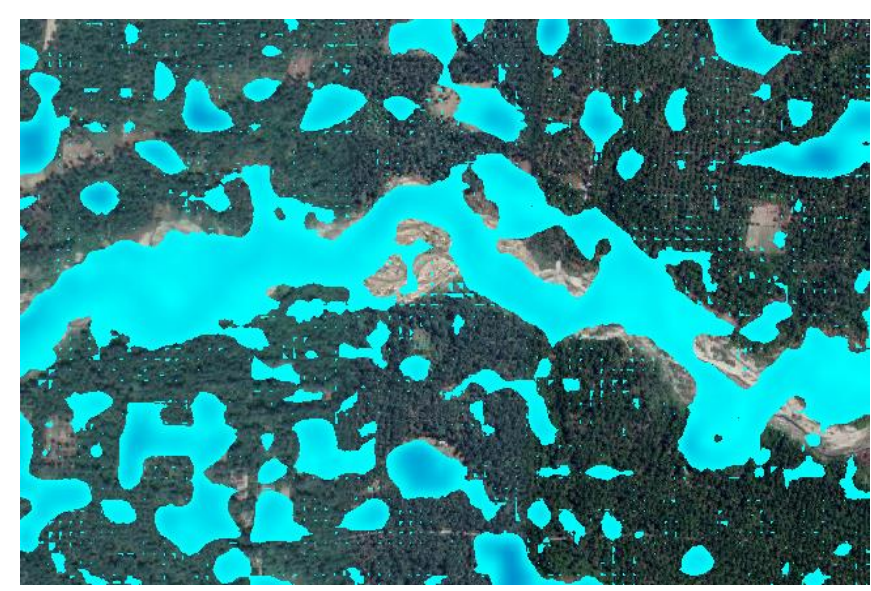

\section{Gambar 7. Kondisi Genangan Banjir di Sub DAS Palu Daerah Sigi}

Berdasarkan simulasi banjir di atas terlihat secara umum banyak wilayah yang akan tergenang banjir dikala hujan tiba. Hal ini tentu menunjukkan bahwa perlunya mitigasi segera terhadap banjir yang akan datang. Kedalaman air permukaan banjir yang terjadi pada tahun 2017 nilainya beragam sebagaimana pada gambar 8 .

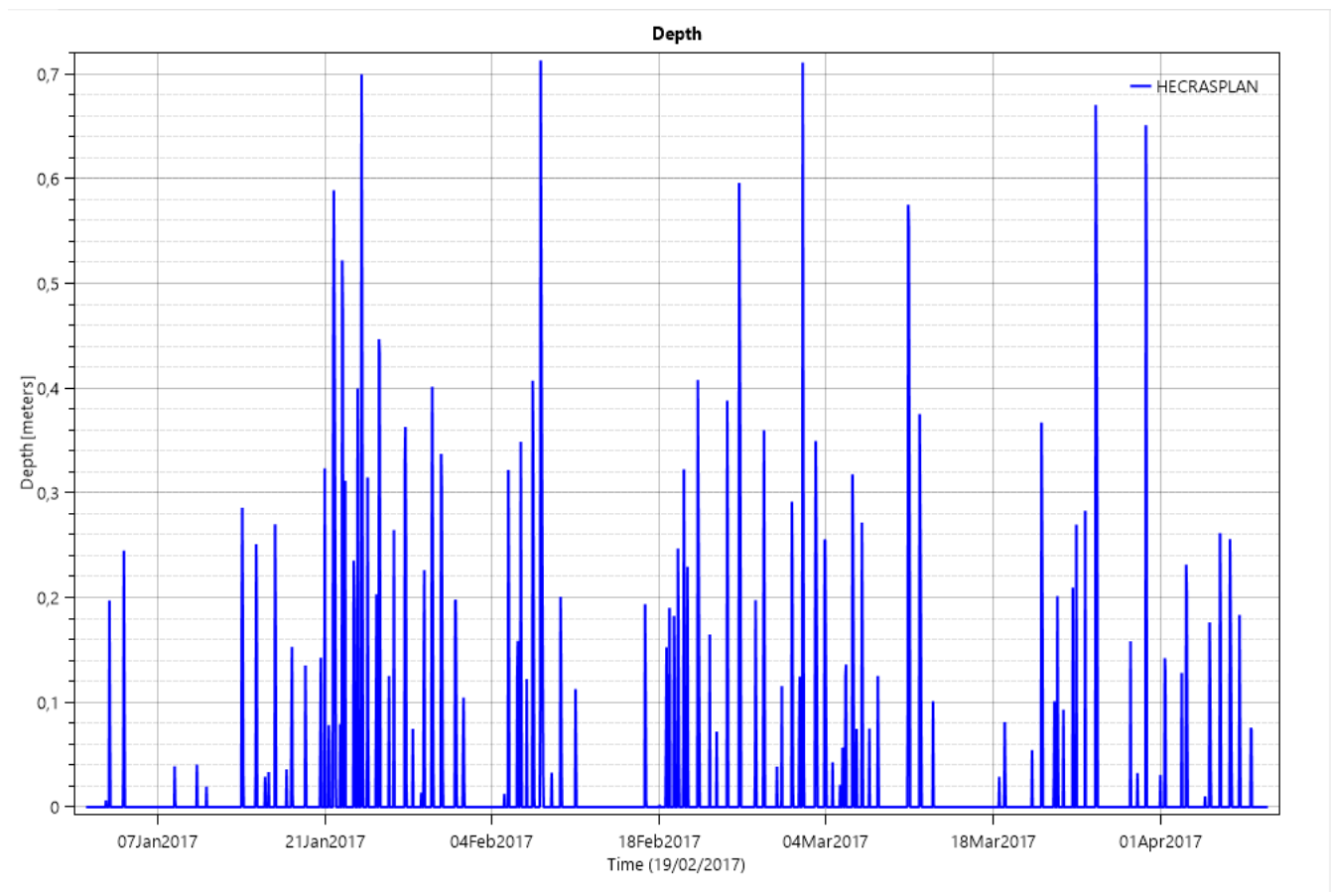

Gambar 8. Kondisi Kedalaman Genangan Banjir di Sub DAS Palu Daerah Sigi 


\section{Kesimpulan}

Berdasarkan hasil analisis simulasi banjir yang dilakukan pada tahun 2017 diketahui ketinggian air banjir maksimum sebesar $70 \mathrm{~cm}$ lebih pada sekitaran wilayah kajian. Hal ini akan terjadi pada tinggi hujan pada rentang $30 \mathrm{~mm}$ hingga $55 \mathrm{~mm}$ di lokasi. Hal ini tentu akan lebih besar lagi untuk curah hujan periodik. Banjir bandang yang terjadi merupakan hasil periodik curah hujan dalam intensitas besar yang datang dan mengalir secara cepat ke wilayah hilir. Dengan demikian, berdasarkan hasil kajian ini terlihat potensi banjir bandang akan terus terjadi mengingat kondisi topografi wilayah yang secara umum datar dan ekstrem pada wilayah hulu. Untuk itu, diharapkan masyarakat yang tinggal diwilayah ini dapat menyesuaikan diri terhadap datangnya banjir yang terjadi secara tiba-tiba.

\section{Ucapan Terima Kasih}

Penulis ucapkan terima kasih kepada Universitas Lampung yang telah memberikan fasilitas sehingga bisa terselesaikannya jurnal ini. Penulis juga berterima kasih kepada rekan-rekan kerja di Fakultas Teknik Universitas Lampung yang telah memberikan motivasi sehingga tulisan ini dapat terselesaikan.

\section{Daftar Pustaka}

Antara. (2017, Juni 04). https://www.beritasatu.com. Retrieved Desember 28, 2020, from Banjir Rendam Ratusan Rumah di Palu: https://www.beritasatu.com/nasional/434597/banjirrendam-ratusan-rumah-di-palu

Chow, V. T. (1994). Applied Hydrology. Texas: McGraw-Hill Book Company.

David Butler And John W. Davies. (2014). Urban Drainage third Edition. London: Spon Press.

Indonesia, T. C. (2018, Oktober 12). Usai Gempa dan Tsunami, Palu Diminta Waspadai Banjir Bandang . Retrieved Desember 23, 2020, from https://www.cnnindonesia.com: https://www.cnnindonesia.com/teknologi/20181011171246-199-337740/usai-gempa-dantsunami-palu-diminta-waspadai-banjir-bandang

Litha, Y. (2019, 12 14). VOA Indonesia. Retrieved 1 13, 2021, from Banjir Bandang di Sigi, Sulteng, 2 Meninggal Dunia: https://www.voaindonesia.com/a/banjir-bandang-di-sigisulteng-2-meninggal-dunia-/5204969.html

Poso, P. (2019, September 3). Banjir Ancaman Serius di Sulteng. Retrieved Desember 23, 2020, from https://kumparan.com: https://kumparan.com/paluposo/banjir-ancaman-serius-disulteng-1rn91pqce1g/full

S.A. Brown, J.D. Schall, J.L. Morris, C.L. Doherty, S.M. Stein, J.C. Warner . (2009). URBAN DRAINAGE DESAIN MANUAL. Colorado: U.S. Department of Transportation.

Subramanya. (1995). Engineering Hydrology. New Delhi: McGraw-Hill Publishing Company Limited.

USACE. (1998). HEC-1 Flood Hydrograph Package User's Manual. Colorado: Hydrology Engineering US Army. 
USACE. (2000). HEC-HMS Technical Reference Manual. Colorado: Hydrologi Engineering Center US Army.

William A. Scharffenberg and Matthew J. Flaming. (2009). Technical Reference Manual HEC HMS. Washinton: US Army Coorp.

Yuan Huang, Feifei Zheng, Huan-Feng Duan, Qingzhou Zhang. (2020). Closure to "Skeletonizing Pipes in Series within Urban Water Distribution Systems Using a Transient-Based Method". ASCE, 146.

Yudi. (2017, Juni 4). Banjir Rendam Ratusan Rumah di Palu. Retrieved Desember 23, 2020, from https://www.beritasatu.com: https://www.beritasatu.com/nasional/434597/banjir-rendamratusan-rumah-di-palu\#! 